ENTREPRENEURSHIP AND SUSTAINABILITY ISSUES

ISSN 2345-0282 (online) http://jssidoi.org/jesi/

2019 Volume 6 Number 4 (June)

http://doi.org/10.9770/jesi.2019.6.4(21)

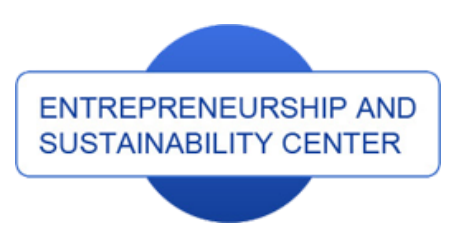

Publisher

http://jssidoi.org/esc/home

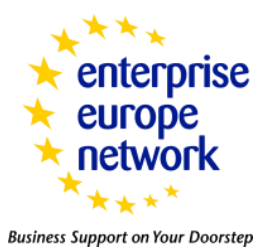

CASPA

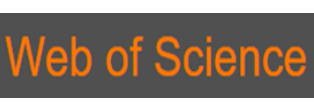

1) Clarivate

Analytics

\title{
A MODEL FOR ESTIMATING SOCIAL AND ECONOMIC INDICATORS OF SUSTAINABLE
} DEVELOPMENT

\author{
Nataliya Dalevska ${ }^{1}$, Valentyna Khobta ${ }^{2}$, Aleksy Kwilinski ${ }^{3}$, Sergey Kravchenko ${ }^{4}$ \\ ${ }^{1,2,4}$ Donetsk National Technical University, 2, Shybankova Square, Pokrovsk, Donetsk Region, 85300, Ukraine \\ ${ }^{3}$ The London Academy of Science and Business, 3rd Floor, 120, Baker Street, London, England, WIU 6TU \\ 1,2,3,4 Institute for International Cooperation Development, 24-26/1, Kazimierza Wielkiego Street, Poznań, 61-863, Poland \\ E-mails: ${ }^{1}$ dalevskanm@gmail.com ; ${ }^{2}$ valentyna.khobta@donntu.edu.ua ; ${ }^{3}$ a.kwilinski@london-asb.co.uk ; \\ ${ }^{4}$ sergey.iv.kravchenko@gmail.com
}

Received 10 December 2018; accepted 10 April 2019; published 30 June 2019

\begin{abstract}
There was developed a methodological approach for carrying out an integrated estimation of the sustainable development socioeconomic parameters based on the UN's current information base. The article proposes a methodology and tools for economic and mathematical modelling to estimate the degree of international trade and investment relations development, the degree of life expectancy, the standard of living and prosperity of international entities under the influence of sources of economic growth. Based on the simulation results an analysis of the general status of the 189 world countries according to the sources of economic growth has been carried out. In order to obtain scientifically grounded results, the paper used general scientific and special methods of research, such as: methods of analysis and synthesis, system approach and abstraction, modelling (fuzzy logic model, a method of Saati hierarchies, Mamdani algorithm), quantitative and qualitative comparison methods, a method of theoretical generalization. The approach proposed in this article can be applied when developing the country's national economic development strategy in the direction of achieving sustainable development.
\end{abstract}

Keywords: fuzzy analysis; economic development; sustainable development; social fragmentation; economic growth; living standards and prosperity of international entities

Reference to this paper should be made as follows: Dalevska, N.; Khobta, V.; Kwilinski, A.; Kravchenko, S. 2019. A model for estimating social and economic indicators of sustainable development, Entrepreneurship and Sustainability Issues 6(4): 1839-1860. http://doi.org/10.9770/jesi.2019.6.4(21)

JEL Classifications: C61, F43 O11

\footnotetext{
* The research was conducted with the support of The London Academy of Science and Business (London, England), Institute for International Cooperation Development (Poznań, Poland), and Ministry of Education and Science of Ukraine within the framework of the research project No. $0116 U 005387$ "Information and communication ensuring of socio-economic development in the globalization context."
} 


\section{ENTREPRENEURSHIP AND SUSTAINABILITY ISSUES}

ISSN 2345-0282 (online) http://jssidoi.org/jesi/

2019 Volume 6 Number 4 (June)

http://doi.org/10.9770/jesi.2019.6.4(21)

\section{Introduction}

The process of any country's development, specificity of implementing economic, social and political transformations in the context of global competition are always associated with a constructive economic development strategy that should be in line with the national interests and global trends in structural change.

Sustainable development is the current imperative of the economic system's structural rearrangement. Consequently, an increase of the world countries' competitiveness is correlated with the economic growth, modernization of the economy and society in accordance with the socio-economic indicators of sustainable development.

Under such conditions, modern theory and practice require elaborating new models of forecasting the economic systems' development, adapted to current realities. Taking into account contemporary integration processes, it is of particular significance to develop models that take into account the current state and prospects of applying factors and reserves to improve the international entities' efficiency in the direction of achieving sustainable development.

The following scholars research the problem of economic growth in the context of sustainable development Kaźmierczyk \& Akulich 2018a, 2018b; Kvilinskyi et al. 2017; Kwilinski et al. 2019; Lakhno et al. 2018; Lankauskienė \& Tvaronavičienè 2012; Luukkanen et al. 2019; Pająk et al. 2016; Raudeliūnienè et al. 2014; Solarin \& Bello 2018; Tkachenko et al. 2019; Tvaronavičienè et al. 2014; Vosylius et al. 2013; Eddelani et al. 2019; Zeibote et al. 2019; Prakash, Garg 2019).

The scientific results obtained are not exhaustive due to the high dynamism and multivariate nature of the available research object. All of the above serve a prerequisite for further research and for setting the purpose of this article: to simulate the estimation of socio-economic parameters of international entities' sustainable development.

\section{Literature review}

At the initial stage, the ecological component dominated the approaches to determining the prerequisites for sustainable development: the Clean Development Mechanism (Karakosta et al. 2009; Edingera \& Kaulb 2000), low carbon growth pathways (Blohmke 2014; Figueroa \& Ribeiro 2013; Karpenko et al. 2018; Mazurkiewicz \& Lis 2015, 2018; Pająk et al. 2017; Razminienè, Tvaronavičienè 2018; Yang et al. 2018), etc. At present, sustainable development provides for a broad range of socio-economic issues along with environmental ones in their interconnection and interaction: relationships between the natural environment and poverty (Schleicher et al. 2018), human rights-based approaches to global challenges (Arts 2017), aligning the Sustainable Development Goals with existing governance arrangements, and integrating the economic, social and environmental dimension (Biermann et al. 2017).

Socio-economic background for sustainable development is determined by economic development and the fight against income inequality. Income inequality quickly grows into inequality of well-being, which negatively affects social mobility - the basis of society's structure. Inequality is a social characteristic of a certain social state of individuals, certain segments of the population, which reflects their civil status, political and legal rights, and their relation to the means of production and its results. Inequality has social and economic aspects. The social aspect determines the people's unequal access to social rights and freedoms (the right to employment, health care, 


\section{ENTREPRENEURSHIP AND SUSTAINABILITY ISSUES}

ISSN 2345-0282 (online) http://jssidoi.org/jesi/

2019 Volume 6 Number 4 (June)

http://doi.org/10.9770/jesi.2019.6.4(21)

medical care, etc.), while economic aspect is associated with the process of income distribution, inequality of opportunities, and discrimination. According to K. A. Nordström and J. Ridderstrale, polarization in the modern society is increasing, and new types of inequalities arise: value, education, information ones, etc. (Nordstrom \& Ridderstrale 2000). Under these conditions, the asymmetry of the world countries' development is growing, which increases the gaps among the living standards of different segments of the population.

Social tension reveals the deepest level of human values and expresses people's true sense of life orientation. From the existential standpoint, sense-of-life values are formed basing on recognition of the objectively rational meaninglessness of existence, which forces an individual to construct his own value system by choosing and taking responsibility for this choice to oneself. Existential level of the value system in this case forms the human resource component of the economic development.

Access to education characterizes the social aspect of the economic development. Together with material wealth, knowledge belongs to the list of scarce resources, the volume of which determines the integral position of an individual in the social space, associated with a specific set of life opportunities. Qualitative education, namely, the new knowledge and ability to use them to form human capital is a momentum of the economic development.

The informational type of fragmentation determines the information environment and the ability to adapt to it. One of the current characteristics of the informational type of fragmentation is the number of the Internet users. The number of Internet users as on July 30, 2018 amounted to 4,208,571,287 people out of the total world population of 7,634,457,932 people (Internet World Stats 2018). According to the research by RetailMeNot Inc., the world's largest producer of digital coupons on the commodity market, the scope of the Internet trade has grown significantly in recent years. The share of Internet commerce accounts for $6.5 \%$ of total retail sales in the world (Centre for Retail Research 2018). It should be borne in mind that the real value of this indicator is higher than $6.5 \%$. This is due to the large number of small online stores, whose activities are virtually impossible to be taken into account. The Internet opens the door to the labour market, which is actively developing in the virtual space. Only Quintessential Careers, the most authoritative and comprehensive career development site according to Forbes, offers over 50 job placement portals. The Internet is an environment for knowledge sharing and access to it. Free access to scientific information leads to an increase in the rate of scientific and technical progress. Given the aforementioned, the number of the country's Internet users should be considered as one of the sources for the economic growth.

It should be noted that the world system's transition towards sustainable development depends on the real socioeconomic opportunities for each country's development. Ensuring the balance of the socio-economic system means overcoming the income inequality and the effective use of the resources promoting the economic development in the interests of the population. Consequently, the socio-economic dimension of sustainable development implies an increase in the quality of life and well-being of the international entities under the influence of sources for economic growth.

\section{Methodology}

This article develops and analyses a set of fuzzy logic models, which determine the index of living standards and prosperity of the international entities under the influence of sources of economic growth. The index of living standards and prosperity of the international entities under the influence of sources of economic growth is determined by the indicators applied by the Human Development Report Office (HDRO) at the United Nations Development Programme (UNDP) in calculating the Human Development Index (HDI). These calculations are based on the statistical values for 189 countries with the most recent data for 2017. Of these countries, 59 are in 
the very high human development group, 53 in the high, 39 in the medium and only 38 in the low (Human Development Report 2018).

A set of models consists of:

1. Model A, a fuzzy logic model for determining the degree of international trade and investment relations development, which forms the component of international trade relations in the general structure of the models set.

2. Model B, a fuzzy logic model determining the degree of life expectancy and the extreme stress component of life, which leads a person to decide on its termination (suicide). The model forms the human resource component in the overall structure of the models set.

3. The Unit for calculating the education index EI, which forms the component of the education duration and availability in the overall structure of the models set.

4. Model C, a fuzzy logic model for determining the index of living standards and prosperity of the international entities under the influence of sources of economic growth. Model $\mathrm{C}$ uses the calculations results of model A, model B, a calculation unit for the education index EI and the following indicators:

- EPR - employment to population ratio;

- IU - Internet users;

- RDE - Research and development expenses.

\subsection{Model A}

The fuzzy logic model for determining the degree of international trade and investment relations development (model A) contains three fuzzy input variables and one output. The value of the resulting variable IR (international rate) reflects the degree of international trade and investment relations development for each of the countries. The value of this indicator is within the range from 0 to 1 . The indicator is a dimensionless quantity. The IR calculation is based on the statistical values of the indicators given in Table 1.

Table 1. The calculated basis for the variable IR model of the degree of international trade and investment relations development

\begin{tabular}{|l|l|}
\hline Parameter name & Parameter definition, according to the UN terminology database \\
\hline International trade (IT) & $\begin{array}{l}\text { A basic indicator of openness to foreign trade and economic integration. It indicates } \\
\text { the dependence of domestic producers on foreign demand (exports) and of domestic } \\
\text { consumers and producers on foreign supply (imports), relative to the country's } \\
\text { economic size (GDP). Trade is the sum of exports and imports of goods and services } \\
\text { measured as a share of gross domestic product. }\end{array}$ \\
\hline $\begin{array}{l}\text { Foreign direct investment, } \\
\text { net inflows (FDI) }\end{array}$ & $\begin{array}{l}\text { Sum of equity capital, reinvestment of earnings, other long-term capital and short- } \\
\text { term capital, expressed as a percentage of GDP. }\end{array}$ \\
\hline $\begin{array}{l}\text { Private capital flows } \\
\text { (PCF) }\end{array}$ & $\begin{array}{l}\text { Net foreign direct investment and portfolio investment, expressed as a percentage of } \\
\text { GDP. }\end{array}$ \\
\hline
\end{tabular}

Source: own processing according to data of the Human Development Report (2018)

The structure of the fuzzy logic model is shown in Figure 1. 


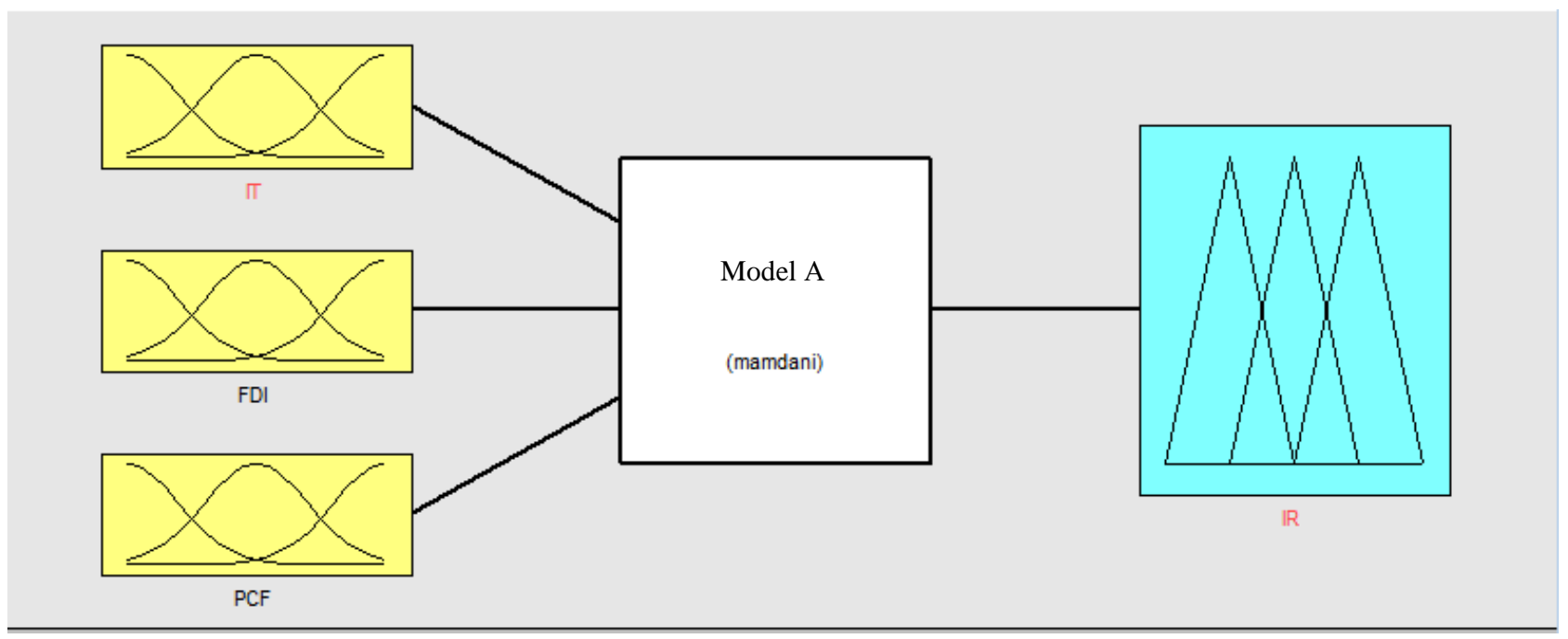

Fig.1. The structure of the fuzzy logic model that reflects the international trade component

Source: authors' research

The structure of the model shown in Figure 1 corresponds to the structure of the fuzzy logical conclusion (Terano et al. 1994). In blocks of IT, FDI, PCF there are phasification processes, that is, the conversion of clear values of variable inputs into a fuzzy form by determining a degree of the input value belonging to its terms. The result of the IR block calculation is subject to de-phasificatios

The rules of the Mamdani fuzzy knowledge base are compiled taking into account the hierarchy of the priorities of the input variables established by MAI Saaty (the Saaty method of hierarchies' analysis) for an agreed matrix of pairwise comparisons (Mamdani 1974; Saaty 2001). Knowledge base rules determine the dependence of IR on IT, FDI, PCF in case the ratios of the specified characteristics are different: extra low - EL; low - L; medium - M; high - H); extra high - EH. Knowledge base rules are as follows:

1. If (IT is L) and (FDI is L) and (PCF is L) then (IR is EL)

2. If (IT is L) and (FDI is L) and (PCF is M) then (IR is EL)

3. If (IT is L) and (FDI is L) and (PCF is H) then (IR is EL

4. If (IT is L) and (FDI is M) and (PCF is M) then (IR is EL)

5. If (IT is L) and (FDI is H) and (PCF is M) then (IR is L)

6. If (IT is L) and (FDI is M) and (PCF is $\mathrm{H}$ ) then (IR is L)

7. If (IT is L) and (FDI is $\mathrm{H}$ ) and (PCF is $\mathrm{H}$ ) then (IR is L)

8. If (IT is M) and (FDI is L) and (PCF is L) then (IR is L)

9. If (IT is M) and (FDI is L) and (PCF is M) then (IR is M))

10. If (IT is M) and (FDI is L) and (PCF is H) then (IR is M)

11. If (IT is $\mathrm{M}$ ) and (FDI is $\mathrm{M}$ ) and (PCF is $\mathrm{M}$ ) then (IR is $\mathrm{M}$ )

12. If (IT is M) and (FDI is $\mathrm{H}$ ) and (PCF is $M$ ) then (IR is M)

13. If (IT is $\mathrm{M}$ ) and (FDI is $\mathrm{M}$ ) and (PCF is $\mathrm{H}$ ) then (IR is $\mathrm{M}$ )

14. If (IT is $\mathrm{M}$ ) and (FDI is $\mathrm{H}$ ) and (PCF is $\mathrm{H}$ ) then (IR is $\mathrm{H}$ )

15. If (IT is $\mathrm{H}$ ) and (FDI is $\mathrm{L}$ ) and (PCF is $\mathrm{L}$ ) then (IR is $\mathrm{H}$ )

16. If (IT is H) and (FDI is L) and (PCF is M) then (IR is H)

17. If (IT is $\mathrm{H})$ and (FDI is $\mathrm{L}$ ) and (PCF is $\mathrm{H}$ ) then (IR is EH)

18. If (IT is $\mathrm{H})$ and (FDI is $\mathrm{M}$ ) and (PCF is $\mathrm{M}$ ) then (IR is EH)

19. If (IT is $\mathrm{H}$ ) and (FDI is $\mathrm{H}$ ) and (PCF is $\mathrm{M}$ ) then (IR is EH)

20. If (IT is $\mathrm{H}$ ) and (FDI is $\mathrm{M}$ ) and (PCF is $\mathrm{H}$ ) then (IR is EH) 
21. If (IT is $\mathrm{H})$ and (FDI is $\mathrm{H})$ and (PCF is $\mathrm{H})$ then (IR is EH)

22. If (IT is $\mathrm{H})$ and (FDI is $\mathrm{H})$ and (PCF is $\mathrm{L}$ ) then (IR is EH)

23. If (IT is L) and (FDI is M) and (PCF is L) then (IR is EH)

24. If (IT is L) and (FDI is H) and (PCF is L) then (IR is EH)

25. If (IT is M) and (FDI is M) and (PCF is L) then (IR is M)

26. If (IT is M) and (FDI is H) and (PCF is L) then (IR is M)

27. If (IT is $\mathrm{H}$ ) and (FDI is $\mathrm{M}$ ) and (PCF is L) then (IR is $\mathrm{H}$ )

It is necessary that the knowledge base is compact, that is, it contains close to the minimum number of rules necessary for an adequate modelling of the studied dependence. With a large number of input variables, the compactness of the knowledge base provides a hierarchical representation of the rules (Rotshtein 1998; Miller 1956).

Terms of a fuzzy logic model are shown in Figure 2.

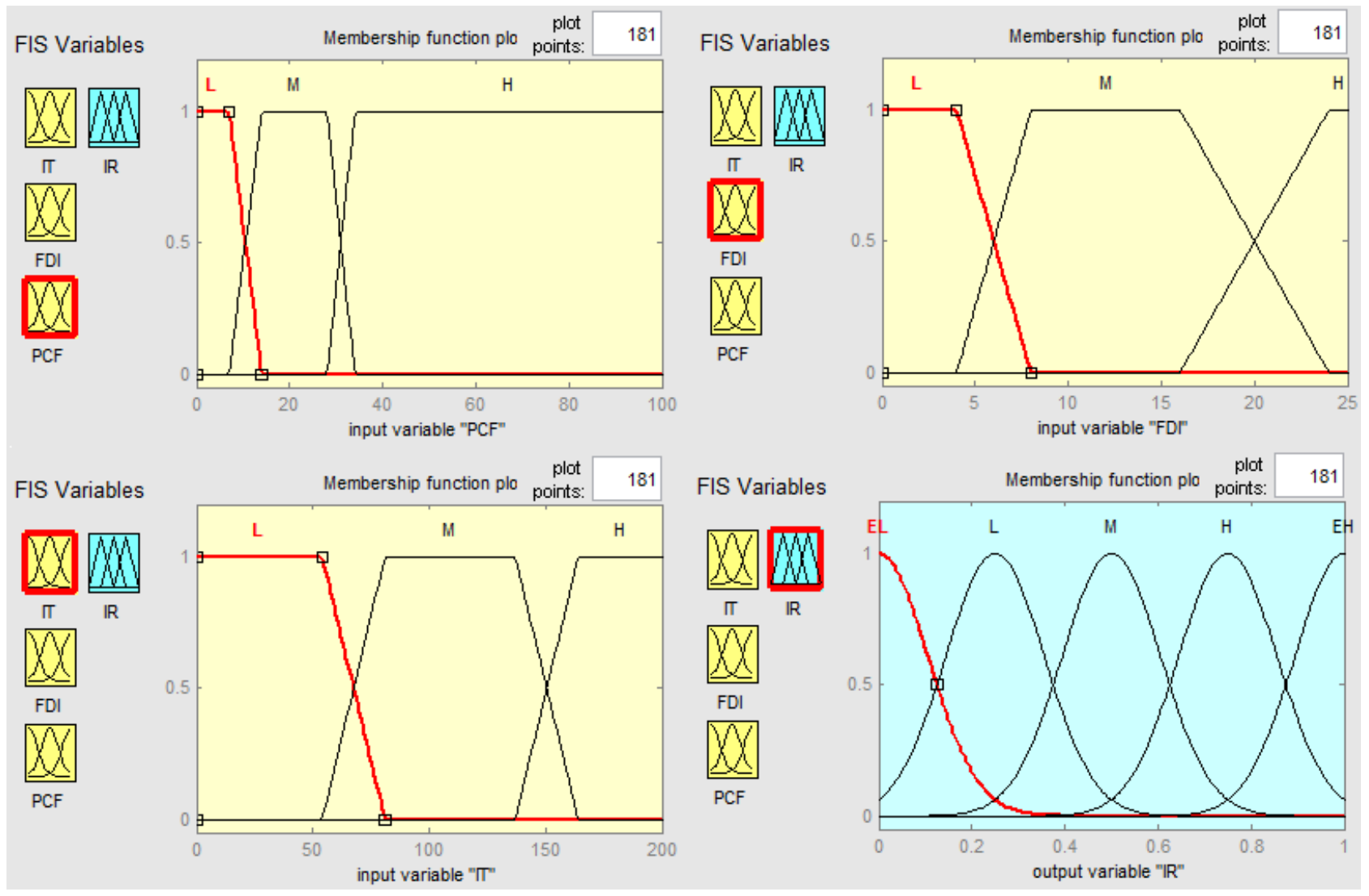

Fig. 2. Graphic representation of the terms of the model, reflecting the degree of international trade and investment relations development Source: authors' research

Figure 2 shows the terms of the model variables. The boundaries of the input variables terms are determined on the basis of statistical analysis of the data for each of the variables.

The graphs of the surfaces reflecting the dependence of the output values on the input values are shown in Figure 3. 


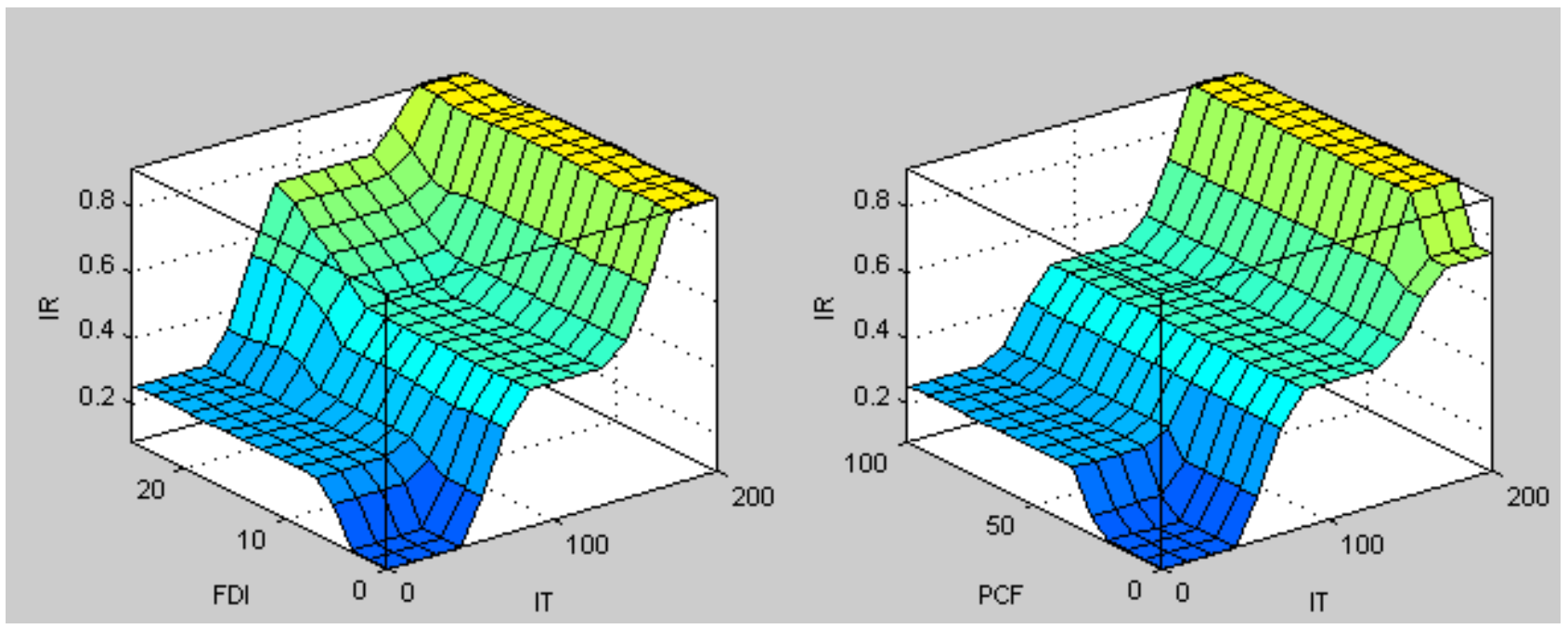

Fig. 3. The graphic representation of surfaces that shows the dependence of the variable IR on variables FDI, IT and PCF Source: authors' research

The surface graphs shown in Figure 3 illustrate the existence of nonlinear dependencies between the input variables and the output variable in the model.

\subsection{Model B}

The fuzzy logic model evaluating the life-cycle (model B) contains two fuzzy inputs and one output. The value of the resulting variable SF (stability fraction) reflects the degree of life expectancy. The value of this indicator is within the range from 0 to 1 . The indicator is a dimensionless quantity. The calculation of SF is based on the statistical values of the indicators given in Table 2.

Table 2. The estimated base of the model's SF variable estimating the life expectancy in the country

\begin{tabular}{|l|l|}
\hline Parameter name & Parameter definition, according to the UN terminology database \\
\hline Life expectancy at birth (LEatB) & $\begin{array}{l}\text { Number of years a new-born infant could expect to live if prevailing } \\
\text { patterns of age-specific mortality rates at the time of birth stay the same } \\
\text { throughout the infant's life. }\end{array}$ \\
\hline Suicide rate (SR) & $\begin{array}{l}\text { Number of death from purposely self-inflicted injuries, in the total } \\
\text { population or of a given sex or age, divided by the total number of the } \\
\text { reference population, expressed per 100,000 people. }\end{array}$ \\
\hline
\end{tabular}

Source: own processing according to data of the Human Development Report (2018)

The structure of the fuzzy logic model is presented in Figure 4. 


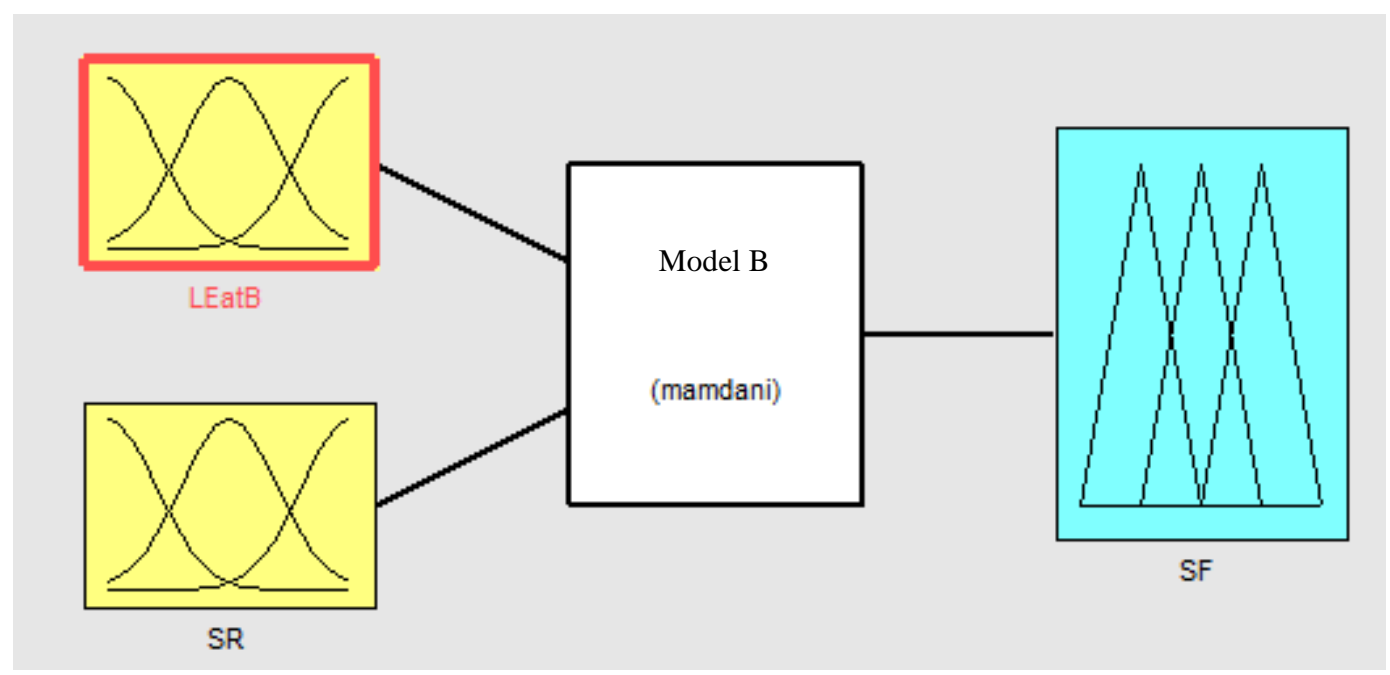

Fig. 4. The structure of a fuzzy logic model that reflects the component of the life duration and marginal stress component in the country Source: authors' research

The structure of the model shown in Figure 4 corresponds to the structure of the fuzzy logic conclusion and involves transformation of the output quantity into a number (the dephasing process) (Terano et al. 1994).

The rules of the Mamdani fuzzy knowledge base are compiled taking into account the hierarchy of priorities of the input variables, established by MAI Saaty according to an agreed matrix of pairwise comparisons. The rules of the knowledge base determine the dependence of SF on LEatB and SR provided the ratios of these characteristics state are different: EL, L, M, H, EH. Knowledge base rules are as follows:

1. If (LEatB is L) and (SR is L) then ( $\mathrm{SF}$ is $\mathrm{H}$ )

2. If (LEatB is $\mathrm{L}$ ) and (SR is M) then (SF is L)

3. If (LEatB is L) and (SR is H) then (SF is EL)

4. If (LEatB is M) and (SR is $\mathrm{L})$ then (SF is $\mathrm{EH})$

5. If (LEatB is M) and (SR is M) then (SF is M)

6. If (LEatB is M) and (SR is H) then (SF is EL)

7. If (LEatB is $\mathrm{H}$ ) and ( $\mathrm{SR}$ is $\mathrm{L}$ ) then ( $\mathrm{SF}$ is $\mathrm{EH}$ )

8. If (LEatB is $\mathrm{H})$ and ( $\mathrm{SR}$ is $\mathrm{M})$ then ( $\mathrm{SF}$ is $\mathrm{H}$ )

9. If (LEatB is $\mathrm{H})$ and ( $\mathrm{SR}$ is $\mathrm{H})$ then ( $\mathrm{SF}$ is $\mathrm{L}$ )

It should be noted that the expected life expectancy at birth (variable LEatB) and the suicide ratio (variable SR) have a different directional effect on the resulting variable SF, which characterizes the life expectancy of the country. There is an inverse proportional relationship between SF and SR. A surface graph describing the output value (SF) dependence on input values (LEatB and SR) is presented in Figure 5. 


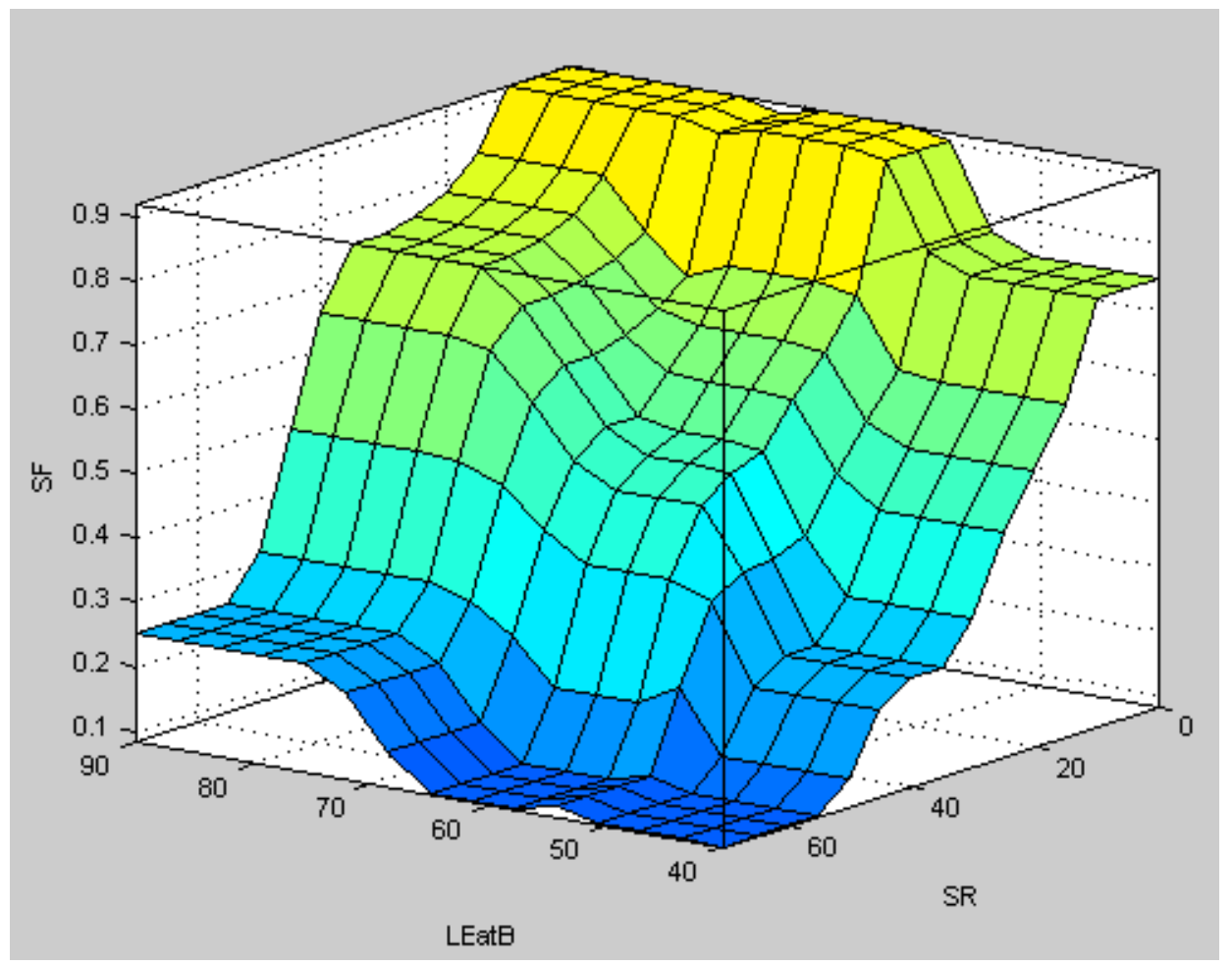

Fig. 5. The graphical representation of the surface, showing the dependence of the SF variable on the variables LEatB and SR Source: authors' research

The surface graph shown in Figure 5 indicates a nonlinear relationship between the input variables and the output variable in the model.

\subsection{Education index}

The calculation of the education index (EI) is based on the statistical values of the indicators given in Table 3 .

Table 3. The calculation basis for the index of education EI

\begin{tabular}{|l|l|}
\hline Parameter name & Parameter definition, according to the UN terminology database \\
\hline Mean years of schooling (MYS) & $\begin{array}{l}\text { Average number of years of education received by people ages 25 and } \\
\text { older, converted from education attainment levels using official durations } \\
\text { of each level. }\end{array}$ \\
\hline Expected years of schooling (EYS) & $\begin{array}{l}\text { Number of years of schooling that a child of school entrance age can } \\
\text { expect to receive if prevailing patterns of age-specific enrolment rates } \\
\text { persist throughout the child's life. }\end{array}$ \\
\hline
\end{tabular}

Source: own processing according to data of the Human Development Report (2018)

Education index EI is calculated by the formula (1): 


$$
E I=\left(\frac{M Y S_{i}-M Y S_{\text {min }}}{M Y S_{\text {max }}-M Y S_{\text {min }}}+\frac{E Y S_{i}-E Y S_{\text {min }}}{E Y S_{\text {max }}-E Y S_{\text {min }}}\right) / 2
$$

where $M Y S_{i}$ - the average number of years of training for the $i$-th country;

$E Y S_{i}$ - expected duration of training for the $i$-th country;

$M Y S_{\max }$ - the maximum number of years of study among countries according to 2017 data;

$E Y S_{\text {max }}$ - the maximum expected duration of education in countries according to 2017 data;

$M Y S_{\min }$ - the minimum number of years of study among countries according to 2017 data;

$E Y S_{\text {min }}$ - the minimum expected duration of education in the world countries according to 2017 data.

The above formula is used by the UN to calculate this index and is given in the technical documentation accompanying the Human Development Report (2018). It also explains the choice of maximum and minimum values, according to the UN experts.

\subsection{Model C}

The fuzzy logic model determining the index of living standard and prosperity of the international entities under the influence of the sources of the economic growth (model C) is a model of the top level of hierarchy. It includes the first two models and the results of calculations of the education index EI. It also comprises three more independent variables shown in Table 4.

Table 4. The calculation base of the model determining the influence of sources of economic growth on the index of living standards and prosperity of the international entities.

\begin{tabular}{|l|l|}
\hline Parameter name & Parameter definition, according to the UN terminology database \\
\hline Employment to population ratio (EPR) & Percentage of the population ages 15 and older that is employed. \\
\hline Internet users (IU) & Percentage of people with access to the worldwide network \\
\hline Research and development expenditure (RDE) & $\begin{array}{l}\text { Current and capital expenditures (both public and private) on creative } \\
\text { work undertaken systematically to increase knowledge and the use of } \\
\text { knowledge for new applications, expressed as a percentage of GDP. It } \\
\text { covers basic research, applied research, and experimental development. }\end{array}$ \\
\hline Gross national income (GNI) per capita & $\begin{array}{l}\text { Aggregate income of an economy generated by its production and its } \\
\text { ownership of factors of production, less the incomes paid for the use of } \\
\text { factors of production owned by the rest of the world, converted to } \\
\text { international dollars using PPP rates, divided by midyear population. }\end{array}$ \\
\hline
\end{tabular}

Source: own processing according to data of the Human Development Report (2018)

Figure 6 presents the overall structure of the final model for determining the index of living standards and prosperity of the international entities under the influence of sources of economic growth.

The structure of the model shown in Figure 6 corresponds to the hierarchical system of fuzzy logical conclusion. The system presented allows establishing multifactorial dependence, using the results of the logical conclusion from the fuzzy knowledge bases of previous levels, namely results of model A and model B. 


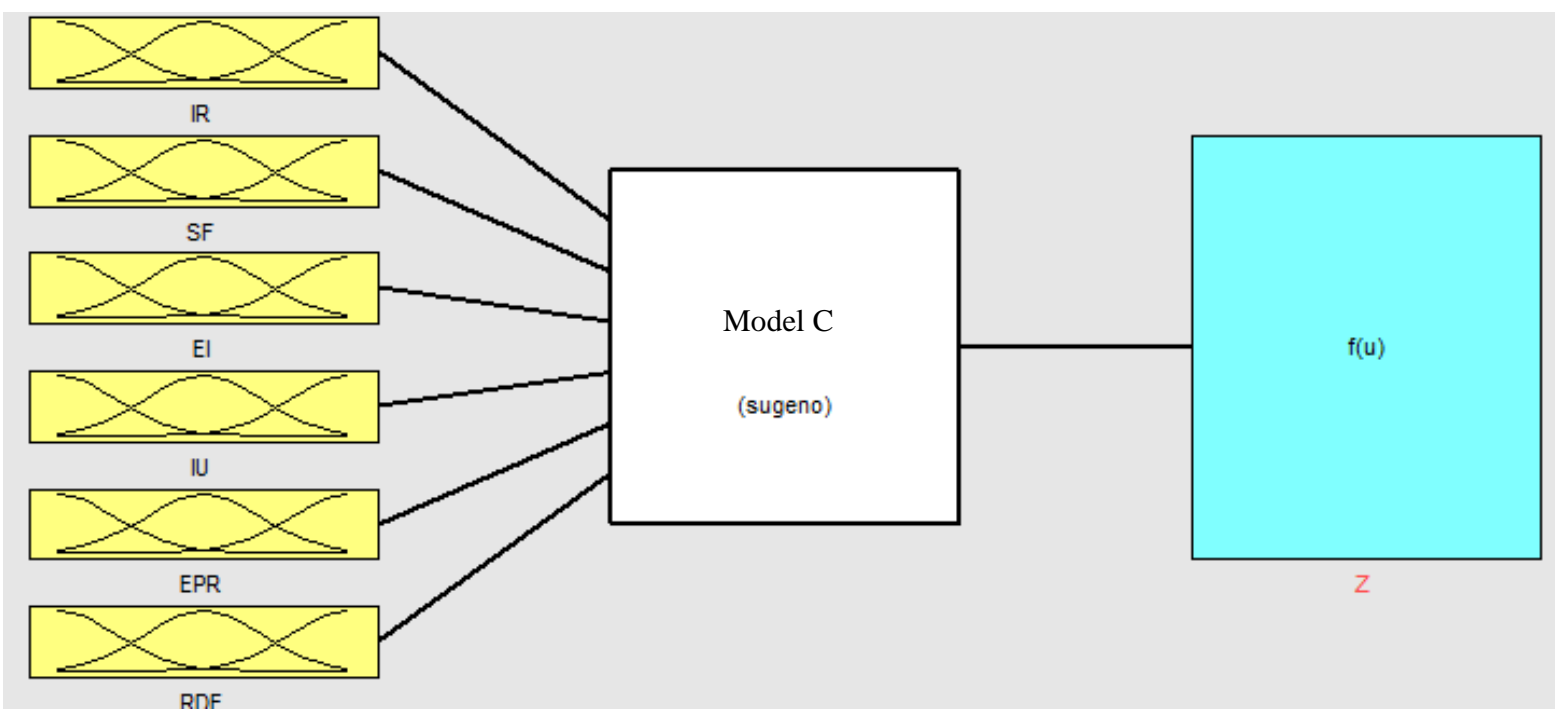

Fig. 6. The structure of the model for determining the index of living standards and prosperity of the international entities under the influence of sources of economic growth

Source: authors' research

In order for the result of the model (variable Z) to be of dimensionless quantity and to show the degree of the country's GNI in comparison with the best values among the countries of the world, but not its absolute dimension, all GNI values should be normalized:

$$
G N I_{i}^{n}=\frac{G N I_{i}}{G N I_{\text {max }}}
$$

where $\mathrm{GNI}^{\mathrm{n}}$ - the normalized value of per capita GNI for the $i$-th country;

$\mathrm{GNI}_{\mathrm{i}}$ - the value of per capita GNI for the $i$-th country;

GNImax - maximum per capita GNI per a country according to 2017 data.

Figure 7 presents the initial multidimensional array of 70 elements to train the model to determine the index of living standards and prosperity of the international entities under the influence of sources of the economic growth.

The abscissa axis in Figure 7 shows the numbers of the ordered elements of a multidimensional array, which includes the following parameters of the model: IR, SF, EI, EPR, IU, RDE. The values of the original variable $\mathrm{Z}$ are within the range from 0 to 1.

The fuzzy model training was carried out using the method of subtractive clusterization (Höppner et al. 1999). This method is used in the case when it is impossible to determine in advance the number of clusters. The algorithm is informed by the ideas of the mountain clustering, which was proposed by Ronald Yager and Dimitar Filev. The specific feature of the method is no necessity to set the number of clusters before starting an algorithm (Shtovba 2007; Karakose \& Akin 2010). In the first step of mountain clustering, there are defined points which can be the centres of clusters. In the second step, for each such point, the potential value is calculated, which shows the possibility of forming a cluster in its outskirts. The more densely are the objects located in the outskirts of the cluster's potential centre, the higher is the value of its potential. After this, the centres of clusters are iterated among the points with maximum potentials. 


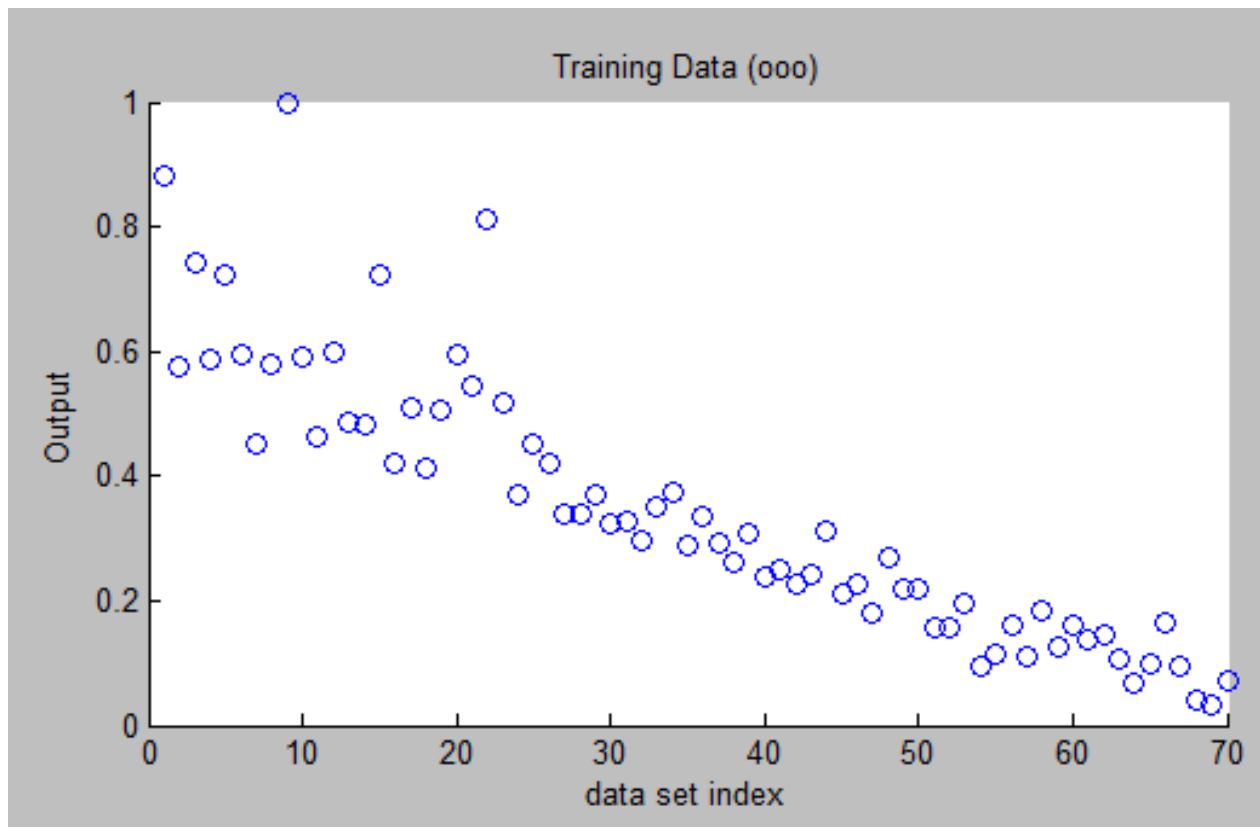

Fig. 7. Initial data

Source: authors' research

The graph of training errors is presented in Figure 8.

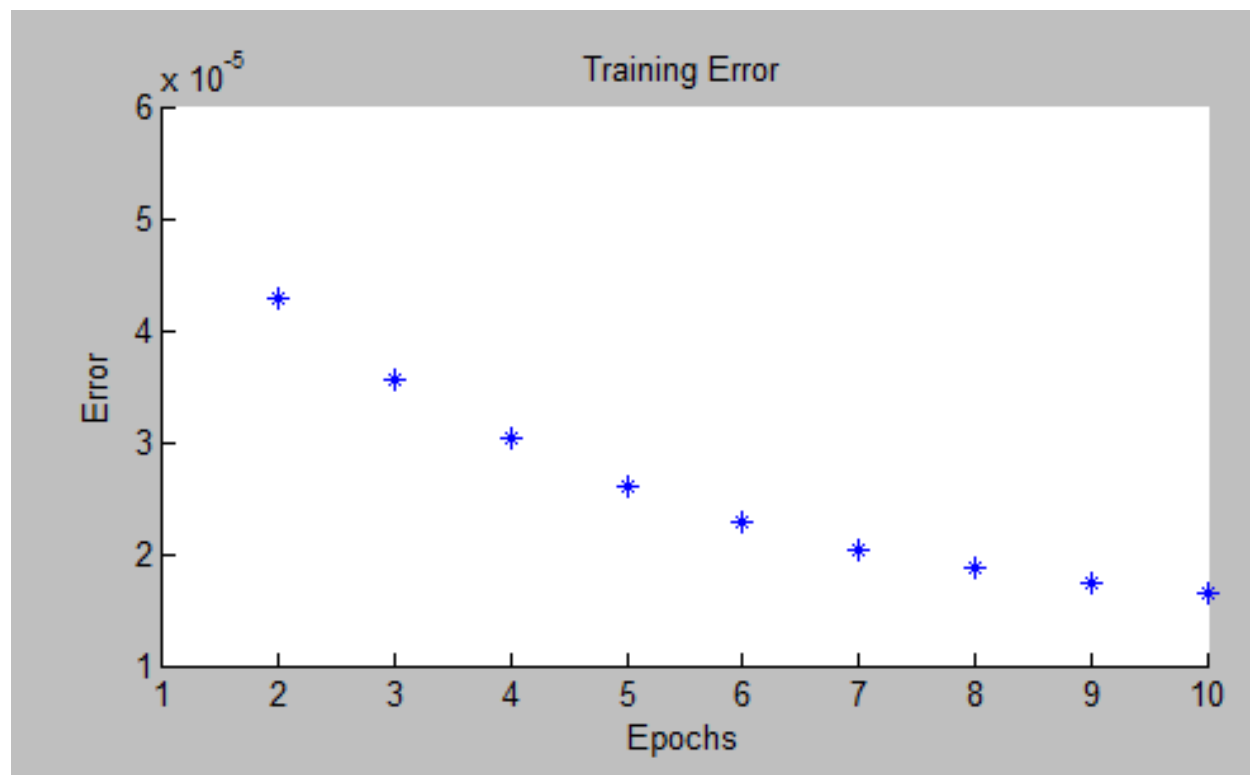

Fig. 8. The error dynamics in the model training process

Source: authors' research

The data presented in Figure 8 indicate that in the model training process the model's error dropped from 0.00006 to 0.00002 . 
Using statistics of a multidimensional array, threshold values are automatically corrected to minimize the model error. In essence, this process represents the fitting of the model, implemented by the algorithms applied, to the existing training data. An error for a model's specific configuration is determined by an iterative run through a model of all available observations and a comparison of the output values calculated using a model with desired (target) values. All such differences are summed up in the so-called error function, the value of which is the model's error (Kendall \& Stuart 1979; Bishop 1996).

The verification of the synthesized fuzzy logic model efficiency in determining the index of living standards and prosperity of the international entities under the influence of sources of the economic growth (model C) according to the output data is summarised in Figure 9.

The results of the model $\mathrm{C}$ testing after its training, presented in Figure 9, indicate that the calculated values of the resulting indicator obtained with the help of the model coincide with its actual values.

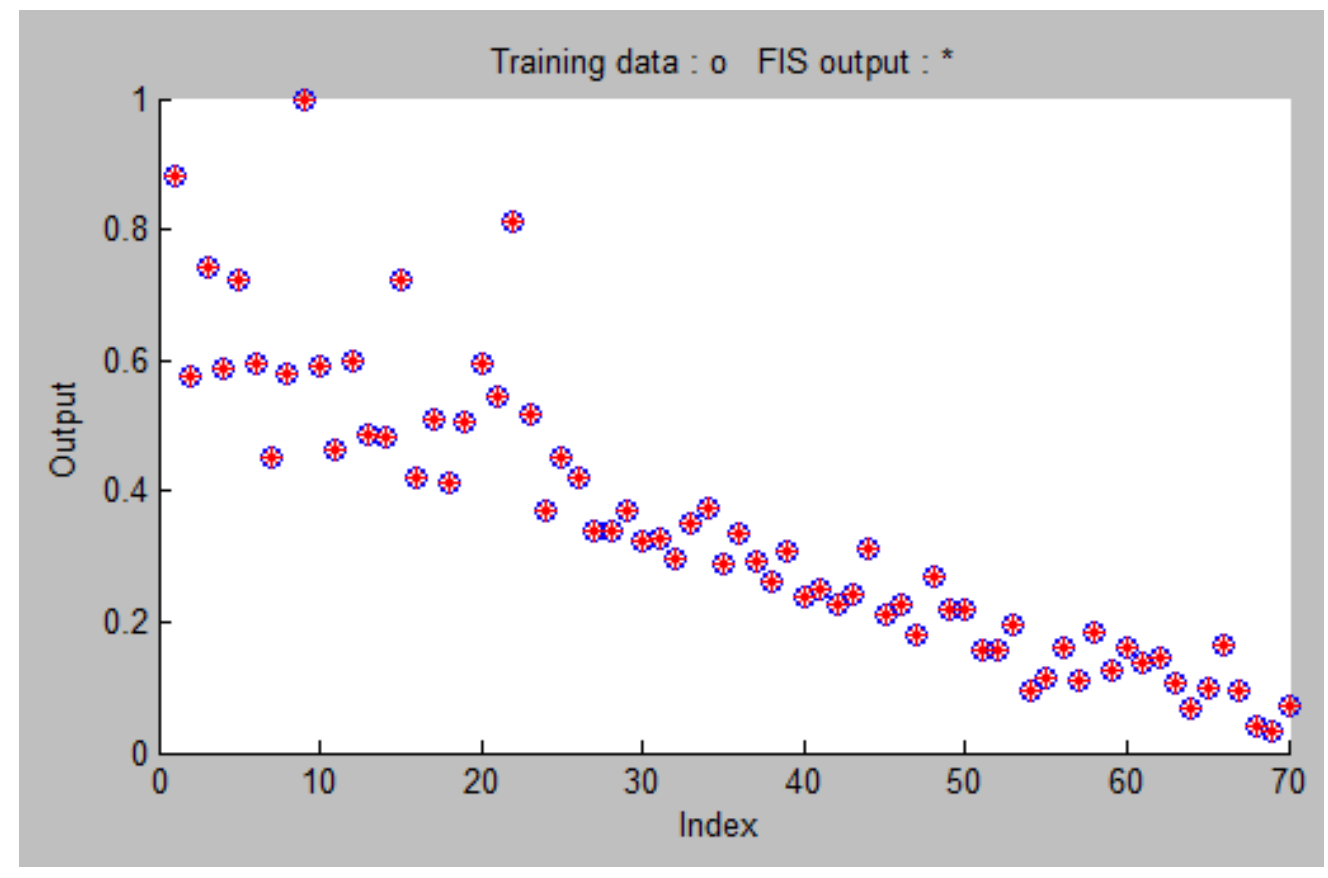

Fig. 9. Results of the model $\mathrm{C}$ testing after its training

Source: authors' research

Figure 10 shows the internal logic of the top-level model $\mathrm{C}$, the input of which has 6 variables, and the base of fuzzy knowledge contains 20 rules. 
ISSN 2345-0282 (online) http://jssidoi.org/jesi/

2019 Volume 6 Number 4 (June)

http://doi.org/10.9770/jesi.2019.6.4(21)

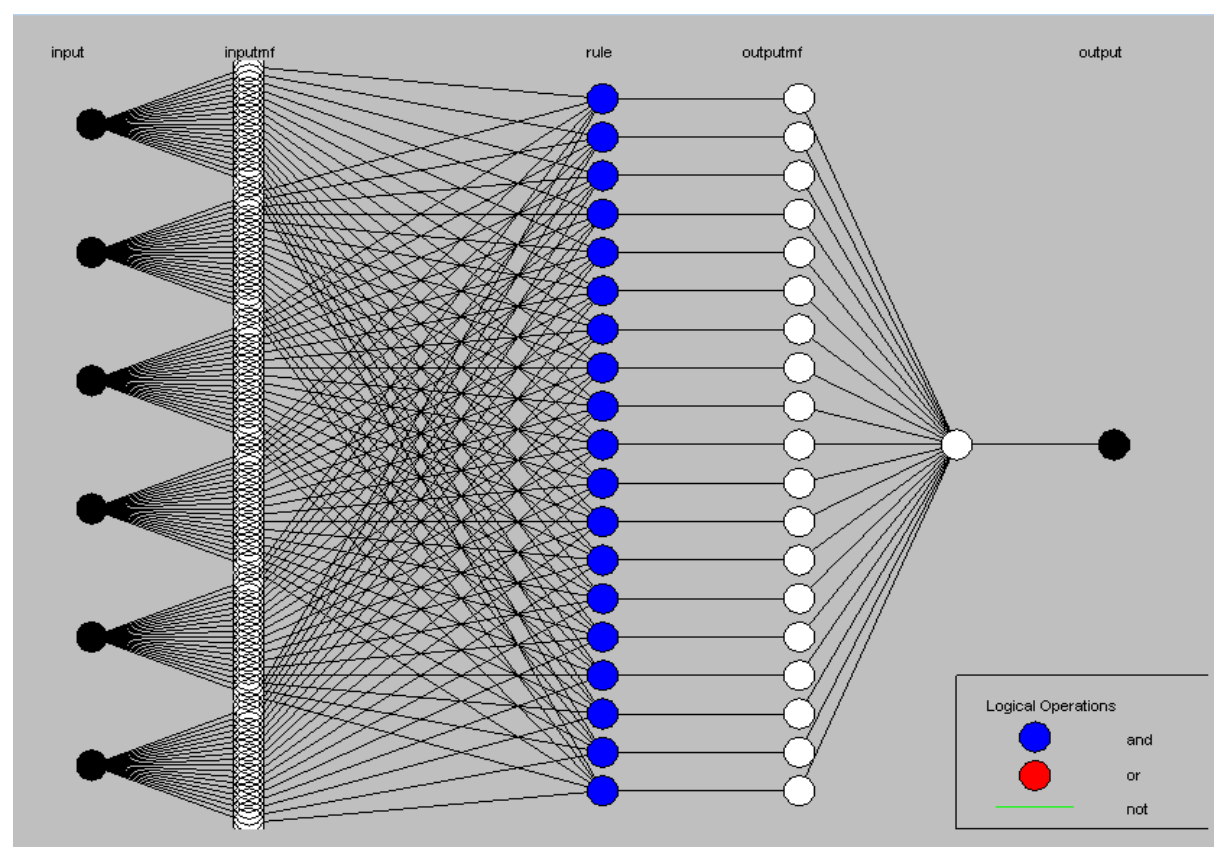

Fig. 10. The internal logic of a model defining the index of living standards and prosperity of the international entities under the influence of sources of the economic growth

Source: authors' research

Figure 11 depicts a graphical representation of the model $\mathrm{C}$ system of rules on the example of Norway.

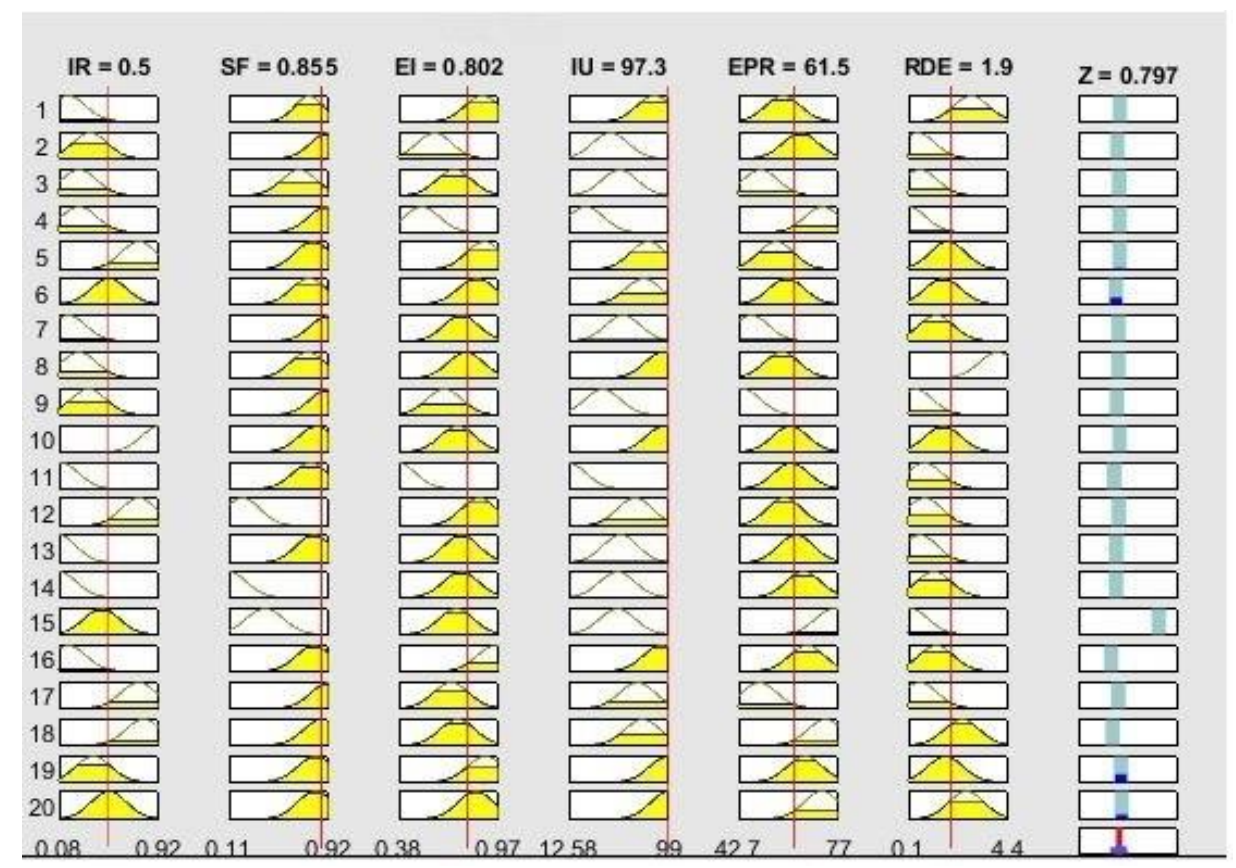

Fig. 11. Calculation of the total index of living standards and prosperity $\mathrm{Z}$ according to Norway's statistical data Source: authors' research 
Figure 11 shows calculation of the total living standard and prosperity index $\mathrm{Z}$ based on Norwegian statistics, which ranks first in terms of HDI according to the UN data as of 2017.

\section{Results and discussions}

The analysis of modelling results suggests that foreign trade is a source of the economic growth, but its large volumes are not an obligatory component in forming a high level of gross national income per capita. This is evidenced by the figures given in Table 5. Countries shown in Table 5 ranked by 2017 Human Development Index (HDI) value.

Table 5. Relationship between the level of living standards and prosperity of the international entities with the level of international trade and investment relations development

\begin{tabular}{|c|c|c|c|}
\hline HDI rank & Country & $\begin{array}{c}\text { Index of international trade and } \\
\text { investment relations development IR }\end{array}$ & $\begin{array}{c}\text { Index of living standards and prosperity } \\
\text { of the international entities Z }\end{array}$ \\
\hline 1 & Norway & 0.50 & 0.797 \\
\hline 5 & Germany & 0.28 & 0.540 \\
\hline 7 & Sweden & 0.35 & 0.559 \\
\hline 10 & Netherlands & 0.79 & 0.561 \\
\hline 14 & United Kingdom & 0.50 & 0.458 \\
\hline 20 & Austria & 0.25 & 0.532 \\
\hline 33 & Poland & 0.50 & 0.306 \\
\hline 36 & Lithuania & 0.65 & 0.332 \\
\hline 71 & Georgia & 0.50 & 0.108 \\
\hline 88 & Ukraine & 0.25 & 0.095 \\
\hline$\ldots$ & $\ldots$ & $\ldots$ & $\ldots$ \\
\hline
\end{tabular}

Source: compiled by the authors based on authors' research and data of the Human Development Report (2018)

The results of calculations summarised in Table 5 indicate that there are countries in which the level of international trade and investment relations development is significantly lower than the average level of this indicator among other countries of the world, but this does not prevent them from achieving a high level of gross national income per capita. Among such countries are Norway, the US, Germany, Japan. Index Z values for these countries are high because of high standards of living and substantial research and development expenses. This is evidenced by the value of the predicted life expectancy at the birth of the LEB $\geq 80$ years and the value RDE $\approx$ $3 \%$.

In the context of international trade and investment relations development, Ukraine has indicators close to the average in comparison with other countries, but due to low values of other parameters of the model (LEB $=72.1$ years, $\mathrm{EPR}=49.1 \%, \mathrm{IU}=52.5 \%, \mathrm{RDE}=0.6 \%$ ), its index of living standards and prosperity of the international entities is very low and accounts for only 0.095. By the level of this indicator's value, Ukraine takes the 111th place among other countries of the world. The countries neighbouring Ukraine in terms of Z indicator are Jordan, Namibia, Indonesia, Mongolia, Jamaica, Armenia, Paraguay, Guatemala, Jamaica.

Under these conditions, potential sources of the economic growth in Ukraine may include:

- research and development expenses RDE, because for countries with high levels of living standards and prosperity, the RDE value is on average $2.5 \%$ of GDP;

- the Internet users' distribution IU, because for developed countries the value of IU is not less than $70 \%$ of the total population of the country.

This is evidenced by the predicted value of $\mathrm{Z}$ indicator, which was obtained by simulation results. 


\section{ENTREPRENEURSHIP AND SUSTAINABILITY ISSUES}

ISSN 2345-0282 (online) http://jssidoi.org/jesi/

2019 Volume 6 Number 4 (June)

http://doi.org/10.9770/jesi.2019.6.4(21)

After all, the increase of the RDE from $0.6 \%$ to $2.5 \%$, which is standard for many developed countries such as France, Austria, Germany, Singapore, Canada, and Australia, will ensure a three-times increase of the $\mathrm{Z}$ index $(Z=0.285)$. The countries closest to the $Z$ indicator's value $=0.285$ are Malaysia, Hungary, Latvia, and Greece.

An increase in the IU indicator from $52.5 \%$ to $62.5 \%$ will result in 2.3 times increase of $\mathrm{Z}(\mathrm{Z}=0.21)$. For 53 countries of the world, such as Norway, Denmark, Great Britain, Canada, Germany, France, USA, Japan, Hungary and others IU values are no less than $70 \%$.

An analysis of the general status of international entities by sources of the economic growth is summarised in Table 6.

Table 6. An analysis of the international entities

\begin{tabular}{|l|c|c|}
\hline \multicolumn{1}{|c|}{ Index } & \multicolumn{1}{|c|}{$\begin{array}{c}\text { The indicator's average value } \\
\text { among the countries of the world }\end{array}$} & $\begin{array}{c}\text { Percentage of countries in which the } \\
\text { indicator's value is less than the average } \\
\text { or the statistical data are missing, \% }\end{array}$ \\
\hline $\begin{array}{l}\text { Index of Development of } \\
\text { International Trade and Investment } \\
\text { Relationships, IR }\end{array}$ & 0.32 & 60.0 \\
\hline Lifecycle index, SF & 0.78 & 55.2 \\
\hline Education index, EI & 0.58 & 45.2 \\
\hline Internet users, IU & $45.7 \%$ & 44.6 \\
\hline Employment population ratio, ERP & $58.6 \%$ & 47.1 \\
\hline $\begin{array}{l}\text { Research and development } \\
\text { expenses, expressed as a percentage } \\
\text { of GDP, RDE }\end{array}$ & $2 \%$ & 85.6 \\
\hline
\end{tabular}

Source: compiled by the authors based on authors' research and data of the Human Development Report (2018)

The results of the calculation shown in this table indicate that, for the indicators RDE, IR, SF, more than half of the world's countries are lower than the average. The worst results are observed in RDE, with only $14.4 \%$ of countries having research and development expenses of more than $2 \%$ of the country's GDP.

Thus, it can be concluded that the greatest potential to influence the countries' economic development is seen in the process of increasing expenditures (both public and private) for research aimed at raising the level of knowledge systematically and at transforming knowledge into new technologies (RDE factor). The optimal level of RDE is $2.5-3 \%$ of the country's GDP, as evidenced by the world experience. The second place among the sources of economic development is taken by international trade and investment relations development (IR) and the improvement of social and economic conditions for living in the country (SF). The third place among the sources of the economic development by their potential belongs to the distribution of the global Internet and the creation of easy-access conditions for the Internet users (IU) and addressing employment problems (EPR). As for the level of education (EI), its low level is now a characteristic feature of Africa, not of the world as a whole.

It should be borne in mind that there are no data on the majority of indicators presented in the UN reports for the vast majority of countries (Cambodia, Congo, Zambia, Nepal, Pakistan, Angola, Zimbabwe, Nigeria, Senegal, Uganda, Afghanistan, Mali, Mozambique and others) in the so-called Low Human Development group. Thus, the lack of data in these countries leads to distortion of the model results at some intervals in the field of determining the input parameters. For the models developed, these are low values intervals of independent variables. The UN researchers use approximation methods, which also distorts the calculations results of the HDI indicator's final value. 
In a number of countries, there are atypical combinations of values used in the model. These are countries whose economies are entirely or largely dependent on the oil or gas trade, such as Qatar, Iran, Iraq, Kuwait, Saudi Arabia, Russia, the People's Republic of China. For the developed set of models, they are the so-called statistical noise. This, in turn, increases the error in the calculations obtained on the basis of the model.

Having excluded from the information matrix the lines with incomplete data, the model $\mathrm{C}$ final training was informed by 70 observations, which covered all groups of countries as much as possible. The training resulted in cluster groups and 20 rules. Model $\mathrm{C}$ gives precise results when input data fall within the range of the clusters found. This is evidenced by the fact that in the training process the model's error has dropped from 0.00006 to 0.00002. But, due to the problem of incomplete initial data in the model, there are "blind" zones (intervals). In case input parameters fall within these intervals, the result of the model calculation can differ considerably from the actual one. It should be noted that the above problem is typical only of model C. It is absent in models A and $\mathrm{B}$, since they are Mamdani type models, and the fuzzy knowledge base (model rules) is composed using MAI Saaty and the economic logic.

The developed set of models was realized in Simulink, which is one of the MATLAB computing modules. Figure 12 presents the models set implementation in Simulink environment on the example of calculating the $\mathrm{Z}$ indicator according to Norway's data.

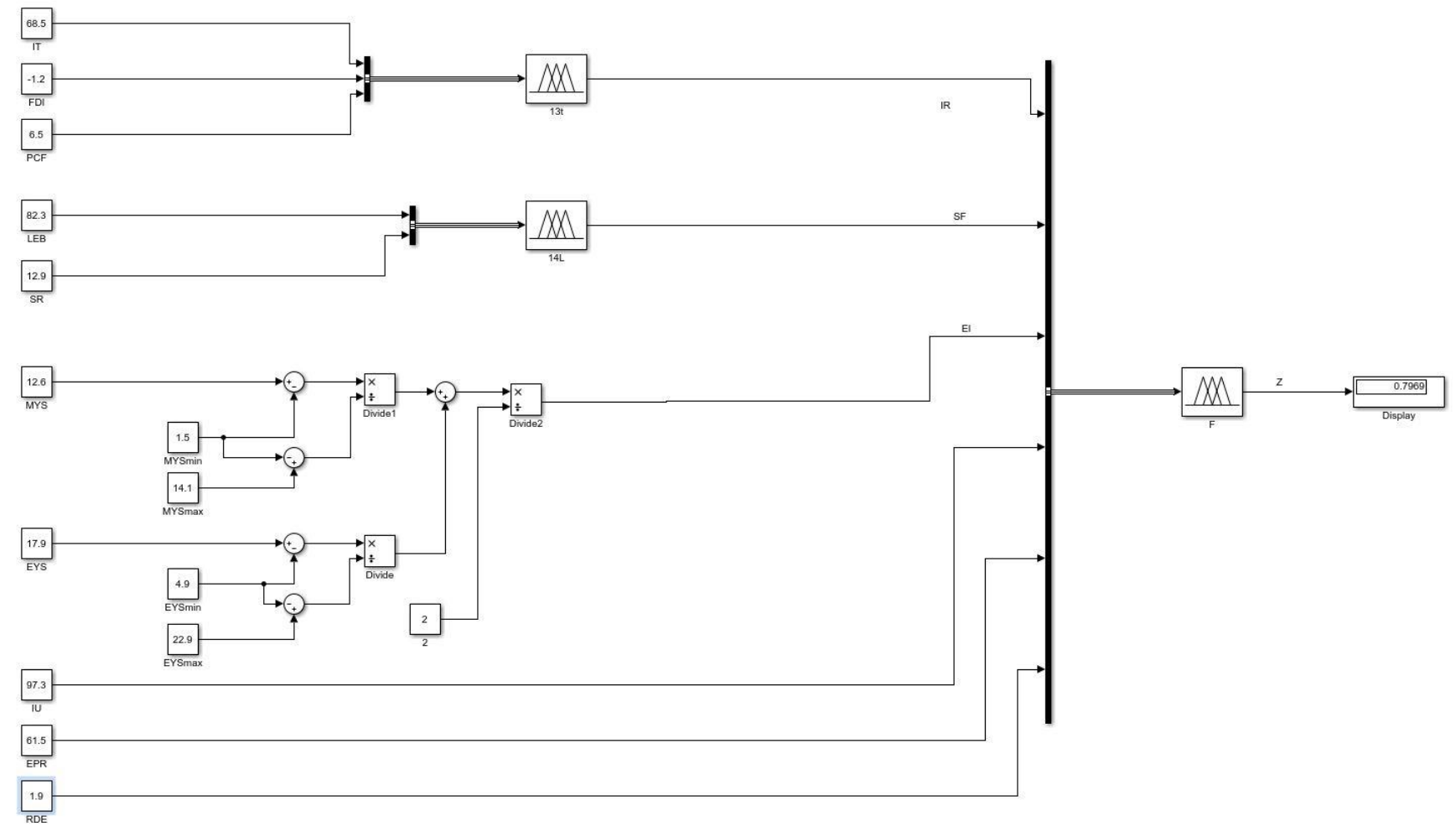

Fig. 12. Implementation of a models set in Simulink Source: authors' research

In Figure 12, the value of the indicator $\mathrm{Z}=0.797$ indicates that this combination of input parameters values (sources of the economic growth) allows generating a high level of gross national income (GNI) per capita (the 


\section{ENTREPRENEURSHIP AND SUSTAINABILITY ISSUES}

ISSN 2345-0282 (online) http://jssidoi.org/jesi/

2019 Volume 6 Number 4 (June)

http://doi.org/10.9770/jesi.2019.6.4(21)

value is close to one) in Norway. Modest use of the income obtained will further increase the potential of the state in order to:

- improve the health care system, health insurance, and implement programs aimed at protecting the environment;

- fund research programs;

- improve the education system to meet the current and future needs;

- provide free access to information;

- solve the problems of employment for the population;

- develop international trade relations.

\section{Conclusions}

The developed set of fuzzy logic models that defines the index of living standards and prosperity of international entities under the influence of sources of the economic growth provides an opportunity to estimate the expected level of gross national income per capita at different combinations of values of independent variables. The result obtained can be used in elaborating the programs of national economies' strategic development in the direction of achieving sustainability.

The software implementation of this set of models provides an opportunity of its automated application to do realtime calculations, which allows performing the function of monitoring the indicators used in the models. Each of the developed models can be used independently or be involved in another set of models depending on the research objectives. That is, each model is a functional, independent unit.

Further studies aimed at developing a comprehensive methodology for quantitative estimation and analysis of the balance level of social and economic system at the national and world levels proves to be a promising area of the research.

\section{References}

Arts, K. 2017. Inclusive sustainable development: a human rights perspective, Current Opinion in Environmental Sustainability 24: 58-62. https://doi.org/10.1016/j.cosust.2017.02.001

Biermann, F.; Kanie, N.; Kim R.E. 2017. Global governance by goal-setting: the novel approach of the UN Sustainable Development Goals, Current Opinion in Environmental Sustainability 26-27: 26-31. https://doi.org/10.1016/j.cosust.2017.01.010

Bishop, C. 1996. Neural Networks for Pattern Recognition. Oxford: Published by Oxford University Press.

Blohmke, J. 2014. Technology complexity, technology transfer mechanisms and sustainable development, Energy for Sustainable Development 23: 237-246. https://doi.org/10.1016/j.esd.2014.09.003

Centre for Retail Research 2018. Retrieved from http://www.retailresearch.org/onlineretailing.php

Eddelani, O.; El Idrissi, N. E.; Monni, S. 2019. Territorialized forms of production in Morocco: provisional assessment for an own model in gestation, Insights into Regional Development 1(1): 6-18. https://doi.org/10.9770/ird.2019.1.1(1)

Edingera, R; Kaulb, S. 2000. Humankind's detour toward sustainability: past, present, and future of renewable energies and electric power generation, Renewable and Sustainable Energy Reviews 4(3): 295-313. https://doi.org/10.1016/S1364-0321(99)00017-9

Entrepreneurship: Investment and Innovation): 1528-2651-22-S1-337: 1-7. 


\section{ENTREPRENEURSHIP AND SUSTAINABILITY ISSUES}

ISSN 2345-0282 (online) http://jssidoi.org/jesi/

2019 Volume 6 Number 4 (June)

http://doi.org/10.9770/jesi.2019.6.4(21)

Figueroa, M. J.; Ribeiro, S. K. 2013. Energy for road passenger transport and sustainable development: assessing policies and goals interactions, Current Opinion in Environmental Sustainability 5(2): 152-162. https://doi.org/10.1016/j.cosust.2013.04.004

Höppner, F. Klawonn, F.; Kruse, R.; Runkler, T. 1999. Fuzzy cluster analysis: methods for classification, data analysis and image recognition. New York: Published by John Wiley \& Sons.

Human Development Report 2018. Retrieved from http://hdr.undp.org/sites/default/files/2018_human_development_statistical_update.pdf

Internet World Stats 2018. Retrieved from http://www.internetworldstats.com/

Karakose, M.; Akin, E. 2010. Block Based Fuzzy Controllers, International Journal of Research and Reviews in Applied Sciences 3(1): 100 - 110. Retrieved from https://www.arpapress.com/Volumes/Vol3Issue1/IJRRAS_3_1_11.pdf

Karakosta, C.; Doukas, Y.; Psarras, J. 2009. Directing clean development mechanism towards developing countries' sustainable development priorities, Energy for Sustainable Development 13(2): 77-84. https://doi.org/10.1016/j.esd.2009.04.001

Karpenko, L.; Serbov, M.; Kwilinski, A.; Makedon, V.; Drobyazko, S. 2018. Methodological platform of the control mechanism with the energy saving technologies, Academy of Strategic Management Journal 17(5): 1939-6104-17-5-271: 1-7. Retrieved from https://www.abacademies.org/articles/Methodological-platform-of-the-control-mechanism-1939-6104-17-5-271.pdf

Kaźmierczyk, J.; Akulich, M. 2018a. The socio-economic approach to the study of main economic systems. Socialism and capitalism. Part 1, Management 22(1): 238-250. https://doi.org/10.2478/manment-2018-0017

Kaźmierczyk, J.; Akulich, M. 2018b. The socio-economic approach to the study of modern economic systems. Post-capitalism. Part 2, Management 22(2): 299-310. https://doi.org/10.2478/manment-2018-0038

Kendall, M.; Stuart, A. 1979. The advanced theory of statistics. Volume II: Inference and Relationship, 4th edition. New York: Published by Macmillan.

Kvilinskyi, O.; Mieshkov, A.; Bondaryeva, I. 2017. Investigation of the social factors of development of society in the territories with transforming environment, Research Papers in Economics and Finance 2(2), 13-19. https://doi.org/10.18559/ref.2017.2.2

Kwilinski, A.; Dalevska, N.; Kravchenko, S.; Hroznyi, I.; Kovalenko, I. 2019. Formation of the entrepreneurship model of e-business in the context of the introduction of information and communication technologies, Journal of Entrepreneurship Education 22(Special Issue 1) https://www.abacademies.org/articles/Formation-of-the-entrepreneurship-model-of-e-business-in-1528-2651-22-S1-337.pdf

Lakhno, V.; Malyukov, V.; Bochulia, T.; Hipters, Z.; Kwilinski, A.; Tomashevska, O. 2018. Model of managing of the procedure of mutual financial investing in information technologies and smart city systems, International Journal of Civil Engineering and Technology 9(8), 1802-1812. Retrieved from http://www.iaeme.com/MasterAdmin/UploadFolder/IJCIET_09_08_181/IJCIET_09_08_181.pdf

Lankauskienè, T.; Tvaronavičienè, M. 2012. Security and sustainable development approaches and dimensions in the globalization context, Journal of Security and Sustainability Issues 1(4): 287-297. http://dx.doi.org/10.9770/jssi.2012.1.4(5)

Luukkanen, J.; Kaivo-oja, J.; Vähäkari, N.; O’Mahony, T.; Korkeakoski, M.; Panula-Ontto, J.; Phonhalathb, K.; Nanthavongb, K.; Reinckec, K.; Vehmasa, J.; Hogarth, N. 2019. Green economic development in Lao PDR: a sustainability window analysis of green growth productivity and the efficiency gap, Journal of Cleaner Production 211: 818-829. https://doi.org/10.1016/j.jclepro.2018.11.149

Mamdani, E. H. 1974. Application of fuzzy algorithms for the control of a simple dynamic plant, Proceedings of the Institution of Electrical Engineers 121(12): 1585-1588. https://doi.org/10.1049/piee.1974.0328

Mazurkiewicz, J.; Lis, P. 2015. Ocena bezpieczeństwa energetycznego w wybranych krajach Unii Europejskiej [The assessment of energy security in selected European Union countries], Rynek Energii 4(119): 11-20. Retrieved from https://www.researchgate.net/profile/Piotr_Lis/publication/281110415_Ocena_bezpieczenstwa_energetycznego_w_wybranych_krajach_U nii_Europejskiej/links/55e07b7508ae2fac471baf2d/Ocena-bezpieczenstwa-energetycznego-w-wybranych-krajach-Unii-Europejskiej.pdf

Mazurkiewicz, J.; Lis, P. 2018. Diversification of energy poverty in Central and Eastern European countries, Virtual Economics 1(1): 2640. Retrieved from https://virtual-economics.eu/VE_1_1/Mazurkiewicz_Lis_2_VE_1_1_2018_26-41.pdf 


\section{ENTREPRENEURSHIP AND SUSTAINABILITY ISSUES}

ISSN 2345-0282 (online) http://jssidoi.org/jesi/

2019 Volume 6 Number 4 (June)

http://doi.org/10.9770/jesi.2019.6.4(21)

Miller, G. A. 1956. The magical number seven, plus or minus two: Some limits on our capacity for processing information, Psychological Review 63(2): 81-97. http://dx.doi.org/10.1037/h0043158

Nordstrom, K. A.; Ridderstråle, J. 1999. Funky business: talent makes capital dance. Stockholm: Published by Bookhouse.

Pająk, K.; Kamińska, B.; Kvilinskyi, O. 2016. Modern trends of financial sector development under the virtual regionalization conditions, Financial and Credit Activity: Problems of Theory and Practice 2(21): 204-217. https://doi.org/10.18371/fcaptp.v2i21.91052

Pająk, K.; Kvilinskyi, O.; Fasiecka, O.; Miśkiewicz, R. 2017. Energy security in regional policy in Wielkopolska region of Poland, Economics and Environment 2(61): 122-138. Retrieved from https://www.ekonomiaisrodowisko.pl/uploads/eis\%2061/11_pajak.pdf

Prakash, R.; Garg, P. 2019. Comparative assessment of HDI with Composite Development Index (CDI), Insights into Regional Development 1(1): 58-76. https://doi.org/10.9770/ird.2019.1.1(5)

Raudeliūnienė, J.; Tvaronavičienė, M.; Dzemyda, I.; Sepehri, M. 2014. Sustainable entrepreneurship through energy stewardship: role of values and behavioral patterns, Entrepreneurship and Sustainability Issues 2(2): 107-117. http://dx.doi.org/10.9770/jesi.2014.2.2(6)

Razminienè, K.; Tvaronavičienè, M. 2018. Detecting the linkages between clusters and circular economy, Terra Economicus 16(4):50-65 https://doi.org/10.23683/2073-6606-2018-16-4-50-65

Rotshtein, A. 1998. Design and tuning of fuzzy rule-based systems for medical diagnosis, in Teodorescu, N.-H.; Kandel, A.; Gain, L. (Eds.). Fuzzy and Neuro-Fuzzy Systems in Medicine. New York: Published by CRC Press, 243-289.

Saaty, T. L. 2001. Decision making with dependence and feedback: the analytic network process: the organization and prioritization of complexity, second edition. New York: Published by RWS Publications.

Schleicher, J.; Schaafsma, M.; Vira, B. 2018. Will the Sustainable Development Goals address the links between poverty and the natural environment?, Current Opinion in Environmental Sustainability 34: 43-47. https://doi.org/10.1016/j.cosust.2018.09.004

Shtovba, S. D. 2007. Proektirovanie nechetkih sistem sredstvami MATLAB [Designing Fuzzy Systems by MATLAB]. Moskva: Published by Goriachaia liniia - Telekom. (in Russian).

Solarin, S. A.; Bello, M. O. 2018. Interfuel substitution, biomass consumption, economic growth, and sustainable development: Evidence from Brazil, Journal of Cleaner Production 211, 1357-1366. https://doi.org/10.1016/j.jclepro.2018.11.268

Terano, T.; Asai, K.; Sugeno, M. 1994. Applied Fuzzy Systems. Boston: Published by Academic Press, Inc.

Tkachenko, V.; Kwilinski, A.; Korystin, O.; Svyrydiuk, N.; Tkachenko, I. 2019. Assessment of information technologies influence on financial security of economy, Journal of Security and Sustainability 8(3): 379-390. https://doi.org/10.9770/jssi.2019.8.3(7)

Tvaronavičienè, M.; Šimelytė, A.; Lace, N. 2014. Sustainable development facets: exporting industrial sectors from inside, Journal of Security and Sustainability Issues 3(4): 37-44. http://dx.doi.org/10.9770/jssi.2014.3.4(4)

Vosylius, E.; Rakutis, V.; Tvaronavičienè, M. 2013. Economic growth, sustainable development and energy security interrelation, Journal of Security and Sustainability Issues 2(3): 5-14. http://dx.doi.org/10.9770/jssi.2013.2.3(1)

Yang, P.; Yao, Y. F.; Mi, Z.; Cao, Y. F.; Liao, H.; Yu, B. Y.; Liangadef, Q. M.; Coffmanb, D. M.; Wei, Y. M. 2018. Social cost of carbon under shared socioeconomic pathways, Global Environmental Change 53: 225-232. https://doi.org/10.1016/j.gloenvcha.2018.10.001

Zeibote, Z.; Volkova, T.; Todorov, K. 2019. The impact of globalization on regional development and competitiveness: cases of selected regions, Insights into Regional Development 1(1): 33-47. https://doi.org/10.9770/ird.2019.1.1(3) 
ENTREPRENEURSHIP AND SUSTAINABILITY ISSUES

ISSN 2345-0282 (online) http://jssidoi.org/jesi/

2019 Volume 6 Number 4 (June)

http://doi.org/10.9770/jesi.2019.6.4(21)

\section{Aknowledgements}

The research was conducted with the support of The London Academy of Science and Business (London, England), Institute for International Cooperation Development (Poznan, Poland), and Ministry of Education and Science of Ukraine within the framework of the research project No. $0116 U 005387$ "Information and communication ensuring of socio-economic development in the globalization context."

Short biographical note about the contributors at the end of the article (name, surname, academic title and scientific degree, duties, research interests):

Nataliya DALEVSKA is the Associate Professor at the Donetsk National Technical University (Pokrovsk, Ukraine) and the Expert at the Institute for International Cooperation Development (Poznań, Poland). Research interests: international political economy, institutional economics, econometrics, international economics, investment and economic development.

ORCID ID: orcid.org/0000-0002-0074-497X

Valentyna KHOBTA is the Professor at the Donetsk National Technical University (Pokrovsk, Ukraine) and the Expert at the Institute for International Cooperation Development (Poznań, Poland). Research interests: investment support, development of business entities, management of innovation, entrepreneurship, microeconomics, macroeconomics.

ORCID ID: orcid.org/0000-0002-2964-3697

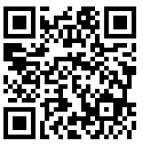

Aleksy KWILINSKI is the Professor at The London Academy of Science and Business (London, England) and the Researcher at the Institute for International Cooperation Development (Poznań, Poland). Research interests: SME, international economics, information economy, globalization, sustainable economic development, development strategies, economic security.

ORCID ID: orcid.org/0000-0001-6318-4001

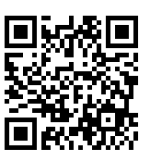

Sergey KRAVCHENKO is the Professor at the Donetsk National Technical University (Pokrovsk, Ukraine) and the Vice President of the Institute for International Cooperation Development (Poznań, Poland). Research interests: investment and innovation activity, science and education management, national innovation systems, change management.

ORCID ID: orcid.org/0000-0001-8391-0445 
ENTREPRENEURSHIP AND SUSTAINABILITY ISSUES

ISSN 2345-0282 (online) http://jssidoi.org/jesi/

2019 Volume 6 Number 4 (June)

http://doi.org/10.9770/jesi.2019.6.4(21)

Copyright (C) 2019 by author(s) and VsI Entrepreneurship and Sustainability Center

This work is licensed under the Creative Commons Attribution International License (CC BY).

http://creativecommons.org/licenses/by/4.0/

cC) (i) Open Access 